\title{
Transnational Labour Solidarity and Social Movement Unionism: Insights from and beyond a Women Workers' Strike in Turkey
}

\author{
Tore Fougner and Ayça Kurtoğlu
}

\begin{abstract}
Through an analysis of solidarity across borders and social groups in connection with and beyond a strike on the part primarily of women workers at a foreignowned factory in Turkey's Antalya Free Zone, this article contributes to the debate on the two union renewal strategies of transnational labour solidarity and coalition building with social movements. In the case at hand, the extensive strike-related support on the part of external unions and the women's movement illustrates the positive difference that solidarity practices can make. However, looking beyond the strike itself, the case points to significant challenges related to the development of deeper and more proactive solidarity across borders and social groups.
\end{abstract}

\section{Introduction}

What are the implications for unions of political economies being restructured in neoliberal terms, and production being re-organized transnationally? This question has generated extensive debate among unionists and academics alike, and one can somewhat synthetically distinguish among a fatalist position viewing the transformations in question as so fundamental that unions are left with few options but to resign, a denialist position considering the transformations as significantly overstated and arguing that unions can rather unproblematically stick to business as usual, and an opportunitist position implying a search for ways through which unions can (re)assert themselves in a world that has changed in important ways. The opportunitist position is reflected in the union revitalization literature, which has identified

Tore Fougner is at the Department of International Relations, Bilkent University. Ayça Kurtoğlu is at the Gender and Women's Studies Graduate Programme, Middle East Technical University. 
several possible 'renewal strategies': organizing new members, internal reorganization and mergers, partnership with employers, political action, coalition building with other social movements, and transnational solidarity (Frege and Kelly 2004).

In this article, we contribute to the debate on the two last-mentioned renewal strategies through an analysis of solidarity across borders and social groups in connection with and beyond a recent strike on the part primarily of women workers in Turkey's Antalya Free Zone. The strike in question was initiated on 26 September 2006, and followed in the wake of a dispute related to working conditions and organizing at a factory owned by Novamed - a subsidiary of the Germany-headquartered company Fresenius Medical Care (FMC), which is the world's leading provider of dialysis products and services. With at least a certain degree of success on the part of the strikers and their union, a negotiated settlement of 18 December 2007 brought the strike to an end. While it is beyond doubt that multi-level and multi-dimensional practices of solidarity contributed positively to the Novamed struggle, the case makes it clear that there are significant challenges involved in the development of deeper and more proactive solidarity across borders and social groups.

We begin by locating the industrial conflict at Novamed within the context of transformations that have occurred in the world political economy since the late 1970s, as well as the industrial relations system in Turkey. In Section 3, we narrate the Novamed workers' struggle to organize and obtain a collective agreement, and this is followed by a closer look at the role played by solidarity practices on the part of external unions and women's groups. Given the post-strike weakness of the union at the workplace, Section 4 considers the prospect for transnational labour solidarity and social movement unionism playing a positive role in connection also with the current situation at Novamed. We conclude with a discussion on union revitalization in the light of the case at hand.

\section{Contextualizing the industrial conflict at Novamed}

The industrial conflict at Novamed can feasibly be contextualized with reference to two elements central to the transformation of the world political economy that have occurred since the late-1970s — namely, the transnationalization of production and the neoliberalization of political economies. Undoubtedly, these processes have been inter-related in that neoliberalization has facilitated the re-organization of production at the transnational level which, in turn, has been extensively used to justify neoliberalization. With Novamed being a foreign-owned subsidiary located in a free zone (FZ) in Turkey, we begin with a look at FMC and the transnational restructuring of the dialysis industry, and proceed with a focus on the establishment of FZs as part and parcel of a shift towards an export-oriented and neoliberal development strategy in Turkey. Finally, we provide an outline of the industrial relations system in Turkey. 


\section{FMC and the World Dialysis Industry}

Facilitated by the liberalization of services trade and FDI, as well as neoliberal 'healthcare reforms' in many countries (Mackintosh and Koivusalo 2005), the dialysis industry has since the early 1990s evolved 'from a local products-oriented business to a global services industry dominated by a handful of big, vertically integrated players' (Medical News Today 23 April 2008). No company exemplifies this development better than FMC. While it made several significant acquisitions in Germany and elsewhere in the early1990s, its 'big leap' abroad and from products to services occurred in 1996, when it acquired National Medical Care, the world's largest dialysis clinic operator at the time (Korine 2000). Currently, FMC is 'the world's largest integrated provider of products and services for individuals undergoing dialysis because of chronic kidney failure' (FMC 2009: 9). Its products and services are sold in more than 100 countries, and the company 'runs a network of more than 30 manufacturing facilities on all continents [and] provides dialysis services in its own dialysis clinics in more than 30 countries' (FMC 2009: 43). As of June 2009, FMC employed 66,364 people on a worldwide basis, and treated 190,081 patients within its network of 2,471 dialysis clinics around the world (FMC Investor News, 4 August 2009). These numbers are higher than for any other company, and FMC dominates also the world dialysis products market, with shares for dialysers and dialysis machines above 45 and 55 per cent, respectively (FMC 2009: 44).

While FMC has been established in Turkey since 1996, the history of Novamed goes back to 1999, when FMC obtained a permission to establish a facility producing dialysis sets in the Antalya FZ. The establishment of Novamed was internal to a strategic decision to move unsophisticated production activities to lower-cost locations, and its rapid growth in production went parallel to a phasing out of and reduction in bloodlines production in Germany and at Fresenius's subsidiary SIS-TER SpA in Italy, respectively. As of 2008, Novamed's 350 or so employees — predominantly young women doing assembly-line shift-work — produced approximately 11 million dialysis sets, which accounted for 40 per cent of FMC's bloodlines production in Europe. While SIS-TER supplies Novamed with the components being assembled in Antalya, about 90 per cent of the final products are trucked to FMC's central warehouse in Germany. ${ }^{1}$ The extent of Novamed's integration into FMC's wider operation becomes additionally clear when it is taken into consideration that SIS-TER's General Manager and Logistics and International Production Manager occupy, respectively, the positions of General Manager and Operational Manager at Novamed.

\section{Turkey and Neoliberal Development}

Turkey's FZ regime was established in the early 1980s as part and parcel of a policy shift from import substitution to export promotion, which, in turn, was integral to broader efforts to neoliberalize economic policies in Turkey. On 24 January 1980, the government announced a comprehensive Economic 
Stabilization Program, the main objectives of which were 'a reduction in government involvement in productive activities and increased emphasis on market forces and the replacement of an inward-oriented strategy, based on import-substitution, with an export-oriented strategy and attraction of foreign investment' (Öniş 1998: 245). While the military coup d'etat of 12 September 1980 led to a significant transformation of the constitutional, legal and political order in Turkey, it merely gave further impetus to the efforts aimed at neoliberalizing the economic policy regime. In what appears as a clear division of labour, the military 'facilitated the adjustment effort by guaranteeing political stability and the exclusion of democratic processes' (Öniş 1998: 138), while the international financial institutions facilitated the restructuring by providing Turkey with a steady flow of cash. When Turkey returned to civilian rule in late 1983, the centre-right Motherland Party established by Turgut Özal — who played a key role in preparing the 1980 structural adjustment program together with the World Bank and the IMF, and was put in charge of economic policy during military rule - won the general election, and secured a continuation of the drive to neoliberalize Turkey's political economy.

Although not mentioned in the economic program of January 1980, the idea of establishing FZs in Turkey made it onto the structural adjustment agenda later that year (IBRD 1980: 19), a General Directorate of Free Zones was established in 1983, and the Free Zones Act was passed by the parliament in 1985. In accordance with conventional justifications for the establishment of FZs, the law's main objectives were to attract foreign capital and increase export-oriented production in Turkey. In order to attract capital, users were exempted from legal provisions related to taxes, levies, duties, as well as foreign exchange and customs obligations. Furthermore, special incentives were provided during the investment and production stages of users' activities, bureaucracy was minimized, and strikes were banned for a 10-year period after a FZ's establishment. Although Turkey's FZ regime has been no great success in investment, employment and trade terms, it nonetheless represented an important attempt to position Turkey within a world political economy increasingly characterized by the free flow of capital.

\section{Industrial Relations in Turkey}

The military leadership that grabbed power in 1980 introduced several measures 'to smash the left and nail down the trade unions' (Nichols and Sugur 2004: 151). While the rights of workers to organize, bargain collectively and strike were recognized in the new Constitution of 1982, legislation introduced by the military in 1983 effectively de-politicized and restricted the activities of unions. Although more recent legislative measures have improved the union situation in Turkey - including the extension in 2001 of the rights to organize and negotiate collectively, though not to conclude binding collective agreements and strike, to the majority of civil servants - the industrial relations system for workers remains governed by the laws introduced by the military. 
The Trade Union Act of 1983 established a dual union structure consisting of industry-based unions, and confederations made up of at least five unions operating in different industries. The law specifies 28 industries according to which unions should be structured, and contains detailed rules and procedures regarding union establishment, membership, organizational structure, finances (un)lawful activities, affiliation to confederation and international union, and auditing and inspection. In 2008, there were 102 workers' unions in Turkey (MLSS 2009: 114), the majority and largest of which affiliated with one of the following confederations: the centre-right Türk-Isş, the left-wing DISK, and the Islamic Hak-Iss. Having benefited from its co-operation with the military regime, the new legislation on collective bargaining (see below) and DISK being disallowed to resume activities before 1992, Türk-Iss is the largest confederation, with 33 affiliated unions and 2.23 million members. DISK currently has 17 affiliated unions and 422,785 members, while Hak-İş, which has benefited from its relationship with the governing Justice and Development Party, has seven affiliated unions and 418,424 members (MLSS 2009: 119).

According to the Ministry of Labour and Social Security (MLSS), the number of workers was about 5.4 million in January 2009, of which 59 per cent was unionized (MLSS 2009: 138). The highest number of unionized workers is found in metalworking, textiles, general services and food industries - with 16, 16, 12.9 and 9.1 per cent of total unionized workers, and union density rates of 75.5, 86.9, 84.8 and 78 per cent, respectively (MLSS 2009: 134). With regard to sex, the unionization rates as of January 2009 were 59.8 and 55 per cent for male and female workers, respectively (MLSS 2009: 144). While the above percentages are fairly high, they are based on statistics that do not reflect reality. First, total employment in Turkey was about 22.3 million in 2006, with labour force participation rates at 24.9 and 71.5 per cent for women and men, respectively (Toksöz 2007: 19). While male employment is concentrated in services (51.1 per cent) and industry (29.1 per cent), the sectoral distribution of female employment is $48.5,15$ and 36.5 per cent in agriculture (unpaid family labour), industry (garment, leather and textiles) and services (community, social and personal services), respectively (Toksöz 2007: 28). Importantly, about 50 per cent of total employment is located in the informal sector (Toksöz 2007: 35), which includes 66 per cent of total female employment - this, in the form of industrial home-based work, domestic services, unpaid family work and traditional handicraft (Dedeoğlu 2008: 50-5) - and is beyond the lawful organizing reach of unions. Second, unions are known to exaggerate their membership figures in order to qualify as collective bargaining agents (see below). Against this background, it is commonly acknowledged not only that the real union density rate in Turkey is about 10 per cent, but also that it is in steady decline (Çelik and Lordoğlu 2006).

The Collective Agreement, Strike and Lock-Out Act of 1983 effectively confined collective bargaining to individual establishments or more than one establishment in the same industry belonging to the same employer. On the

(C) Blackwell Publishing Ltd/London School of Economics 2010. 
union side, the competence to conclude collective agreements rests with industrial unions, and a union must represent as members both 'a minimum of ten per cent of the employees working in the [industry] where [it] is active' and 'more than half of the employees in the establishment[s] ... where it intends to conclude a collective agreement' (Dereli 2006: 297) in order to obtain a certificate of authorization from the MLSS. When such a certificate has been obtained, a union has 15 days to invite the employer to meet for negotiations, and the parties have 60 days to reach an agreement before the bargaining is referred to compulsory arbitration lasting a maximum of 15 days. Industrial action becomes a lawful option only after failed arbitration, and a strike decision must be made 7-12 days following the arbiter's report, communicated to the employer within six days, and implemented within the next 60 days. To prevent surprise strikes, the implementation date must be notified to the employer six days in beforehand. ${ }^{2}$ Any failure to comply with deadline and notification requirements results in the authorization certificate being declared void. About 1.26 million workers (63 per cent of which unionized) were covered by a collective agreement as of July 2009; 146 out of 521 collective bargaining disputes were settled through compulsory arbitration in 2008; and there were 15 strikes involving 38 workplaces and about 5,000 workers, and resulting in 145,000 lost workdays in 2008 (MLSS 2009: 45, 50, 63).

Overall, the legal framework in Turkey does not fully respect core workers' rights (Weisband and Öner 2007). Furthermore, private sector workers commonly suffer 'brutal anti-union harassment, including dismissals' (ITUC 2008). Turkey was recently declared 'the country with the worst record of dismissals ... of workers involved in trade union activity' (ITUC 2009), and a survey has found that 36 per cent of non-organized workers do not join a union because they are 'afraid of being fired from work' (Adaman et al. 2009: 182). Union hostility and anti-union practices are integral to the 'deep structure' of industrial relations in Turkey (Yildrim and Calis 2008), and occur within a legitimizing context in which state authorities are intolerant of union activity' (ITUC 2009), and show no intention whatsoever to crack down on anti-union behaviour. The courts seldom call for the reinstatement of unlawfully dismissed workers, and employers willingly pay a small fee rather than heed such calls.

\section{The industrial conflict at Novamed}

In September 2004, some workers at Novamed initiated an organizing campaign motivated primarily by two factors: First, dissatisfaction with the salaries. While above the minimum wage and not the lowest within the Antalya FZ, the salaries were supposedly below those found in companies within similar lines of business in Turkey. Second, dissatisfaction with the more general working conditions at Novamed. According to the organized workers and their union, the conditions at the time when the organizing was 
initiated included queuing for permission to become pregnant, toilet use monitoring, the need for permission to get married, restrictions on communication among workers, very short work breaks, various kinds of humiliating treatment and attempts to control what workers did outside of work (Petrol-İş 2008: 8, 32). ${ }^{3}$

The organizing was initiated by three male workers in co-operation with the regional branch of the Türk-İş affiliated Petroleum, Chemical and Rubber Workers' Union of Turkey (Petrol-Işs), and done secretly through either the establishment of small groups of workers, or one-to-one communication with them. In both cases, they utilized community-based relations and also engaged directly with some of the women workers' families. Although the organizing proceeded well — with 158 out of 264 workers organized by April 2005 - it became known to the management, which allegedly engaged in both general intimidation and psychological blackmailing (e.g. by stressing that the workers were indebted to them for their jobs, and threatening to move the factory abroad, and make the working conditions worse if there was a union), and individualized harassment and humiliation (e.g. by giving known union members more heavy work loads or schedules, and cross-interrogating workers suspected of being or considering to become organized) (Petrol-İş 2008: 80, 228). ${ }^{4}$

On 11 May 2005, Petrol-İş applied to the MLSS for an authorization certificate at Novamed. Although the number of organized workers had dropped to 136 by then, it still constituted the required majority. When Petrol-İs was recognized as having organized the majority of workers in June 2005, Novamed filed a court case claiming that both the MLSS's sector designation and the reported numbers of Novamed employees and unionized workers were erroneous. These claims were rejected by the Antalya Labour Court in December 2005, and Novamed's appeal was rejected by the High Supreme Court two months later. Although Petrol-İs was finally granted a certificate to bargain on behalf of the workers in March 2006, the legal challenge delayed the point at which it could engage in collective bargaining, and allegedly gave the management additional time to counter the organizing (Petrol-İş 2008: 139-41). Two organized workers were dismissed in late-2005, and union membership declined from 136 to 117 during the court case.

Petrol-İş and Novamed met four times for negotiations in April and May 2006, but could not resolve certain disputes related primarily to financial issues. In consequence, the negotiations were declared inconclusive, and the dispute was referred to compulsory arbitration. This led nowhere, however, and Petrol-İs was left with the options of deciding to call a strike or losing its certificate. While acknowledging its weakness related to both a minority of workers being organized, and a prospective strike involving primarily young women with no prior union experience, it decided to call a strike. Importantly, this would be followed by organized workers requesting a strike ballot, and the hope was that a negative result would enable Petrol-İs to refer the case to the High Court of Arbitration for final settlement. ${ }^{5}$ However, when the ballot was held in late-August 2006, non-organized workers showed 
up in force and voted in favour of strike - this, allegedly, with the support of the management (Petrol-İş 2008: 16). Left with the options of going on strike or losing its certificate, the union initiated a strike on 26 September 2006.

At the outset, the prospect for the strike to succeed was bleak. First, only 85 organized workers went on strike, and they counted for little more than 26 per cent of the workforce. In this connection, it should be noted that Novamed had increased the workforce in the run-up to the strike by recruiting 49 new workers in the period between the break-down of negotiations and the strike announcement, and 26 additional workers in the period between the announcement and initiation of the strike. ${ }^{6}$ Second, the strikers were for the main part women assembly workers rather than male workers occupying more strategically important positions (e.g. technicians, laboratory workers and sterilization personnel), and whose absence from the workplace would have made it more difficult for Novamed to maintain business as usual. However, despite the weakness related to the strike's insignificant impact on FMC's bloodlines production - this, due partly also to FMC's ability to shift production to subsidiaries in Belarus and Italy as well as an independent firm in Greece ${ }^{7}$ - the strikers remained resilient, negotiations between Petrol-İş and Novamed were re-initiated in late-October 2007, and a three-year collective agreement was concluded on 18 December 2007.

\section{Solidarity across Borders and Social Groups in the Novamed Struggle}

What was achieved in and through the strike at Novamed was a product of efforts made not merely by the strikers and their union, but also by their supporters inside and outside of Turkey. While we have elsewhere provided a comprehensive mapping of the solidarities at work in the Novamed struggle, and argued that it was the totality of mutually reinforcing solidarity practices across levels, borders and social groups that made a positive difference (Fougner and Kurtoğlu 2010), we will here look closer at two key elements of the support in question - namely, solidarity practices on the part of external unions and women's groups, respectively.

\section{External Union Support}

The strikers and Petrol-İş received strong support from several unions located outside of Turkey. To some extent, this was a product of conscious efforts on the part of Petrol-Iss to engage external unions at an early point. Based on its positive experience with external union support in connection with another industrial conflict in late-2004, Petrol-İş informed the German Chemical, Mining and Energy Industrial Union (IG BCE), the European Mine, Chemical and Energy Workers' Federation (EMCEF) and the International Federation of Chemical, Energy, Mine and General Workers' Union (ICEM) that they would organize Novamed workers already in January 2005. Upon requests for assistance related to problems faced at the 
workplace, IG BCE and EMCEF provided Petrol-Iss with information about FMC, and brought cases of worker harassment and union repression to the attention of the FMC management either directly, or through the Fresenius European Employee Forum. Such actions supposedly contributed to restrain the worst excesses of anti-union campaigns, and it is fully plausible that the organizing efforts would have come to nothing had it not been for the early external union support.

Following the initiation of the strike in September 2006, external unions engaged in various activities aimed at supporting the Novamed strikers. First, they initiated and/or participated in various solidarity campaigns. Petrol-İs initiated an online LabourStart campaign in late-October 2006, which received 2,178 supporters before it was closed. Furthermore, EMCEF prepared a 'protest letter' in October 2006, while ICEM prepared a 'support letter' in connection with 8 March 2007. Lastly, union feminists participating in women's solidarity platforms (see below) circulated calls for solidarity in connection with the one-year strike anniversary. In response, a large number of national, sectoral and international union representatives from across the world sent support faxes and emails to the strikers and Petrol-İş, and protest faxes and emails to Novamed and FMC managers. Although the effect of such tele- and cybersolidarity is difficult to measure (Robinson 2008) and might be declining (Lee 2006), it contributed significantly both to strengthen the morale and resilience of the strikers and their union, and to mount pressure on the FMC management to resolve the conflict.

Second, external unions organized solidarity visits to Antalya, with the EMCEF General Secretary and an IG BCE International Department representative visiting Novamed in April 2007, 16 energy-sector union leaders from various countries visiting the picket line in May 2007, the ICEM General Secretary and Chemicals and Rubber Industries Officer visiting the strikers in August 2007, and a four-person ICEM Women's Committee delegation paying a visit in connection with the one-year anniversary of the strike. In addition to boost the morale of the strikers, such solidarity visits contributed also to give the strike publicity. Third, they engaged in quiet diplomacy vis-à-vis the FMC management in Germany in order to get the dispute resolved. Such bypassing of the local stalemate proved important, and a meeting between FMC managers and representatives of IG BCE, EMCEF and ICEM in late-September 2007 paved the way for a re-initiation of the local negotiations that led to a collective agreement at Novamed.

\section{Support from Women's Groups}

The Novamed strikers received steadily growing support from women's groups in Turkey in the wake of 8 March 2007. In this connection, two enabling factors should be emphasized: First, the strike was (re)conceptualized as a 'women's strike' through a dialogical process involving union officials (a feminist included) in Petrol-İş and ICEM around New Year 2007, and, second, Petrol-İş organized the strikers' celebration of the International 
Women's Day in Antalya and Istanbul. The former contributed to make the strike relevant to the women's movement in Turkey (Kurtoğlu and Fougner 2008) - which, in contrast to the labour movement and inspired by secondwave feminism, thrived as an autonomous movement in the 1980s (Arat 2008: $397 \mathrm{ff}.)^{8}$ — and the latter became the occasion on which many feminists learned about the strike and met with some of the strikers. While this sparked off initiatives like Filmmor Women's Cooperative making a documentary film on the Novamed strike, it took until the end of the summer for a group of socialist feminists in Istanbul to take more comprehensive action in relation to what they conceived as women's exploitation at the intersection of patriarchy and neoliberalism. Having learned through a union feminist at Petrol-İs that the ICEM Women's Committee would send a delegation to Antalya in late-September 2007, they decided that they should also make a contribution, and established the Women's Platform for Solidarity with Novamed Strikers with the participation of 29 feminist groups and women representatives of unions, professional organizations and political parties.

Within a few weeks, they prepared posters and leaflets, initiated email- and fax-based support and protest campaigns, ran information stalls in busy Istanbul streets, collected signatures to be submitted to the parliament, organized demonstrations in front of FMC's Istanbul office, collected money for the strikers, established a press commission to get media attention, and circulated information through various networks. Inspired by these activities, similar platforms and actions were initiated in several other cities, and, on the day of the one-year strike anniversary, feminists from across Turkey travelled to Antalya in a show of solidarity with the strikers. While this action played an important role in strengthening the strikers' determination to maintain the struggle, the overall actions on the part of feminist groups contributed significantly both to make the women strikers visible, and to FMC being portrayed on the Internet and beyond as a company engaged in superexploitation of women workers in Turkey. Given FMC's image as an 'ethical company', the negative publicity had a significant impact on FMC wishing to get the industrial conflict resolved.

\section{Solidarity with Novamed workers beyond the strike}

While the campaign to organize and obtain a collective agreement at Novamed proved successful in many respects, Petrol-İşs position at the workplace is far from secure. Reflecting in part the dismissal in July 2009 of an organized worker actively involved in union activities, workers remain fearful of joining the union, and the number of union members might well be below the required threshold when the current agreement expires. Against this background, we will explore the prospect for transnational labour solidarity and social movement unionism playing a positive role in relation to the situation in which the workers and Petrol-İş currently find themselves at 
Novamed. The rationale for doing this is threefold: First, solidarity across borders and social groups made a significant positive difference in connection with the strike at Novamed. Second, social movement unionism and transnational solidarity are often highlighted as being among the most promising union responses to neoliberal and transnational restructuring (Bieler et al. 2008; Moody 1997). Third, Petrol-İş seems committed to transnational labour solidarity and coalition-building with other social movements as key elements of its current strategy (Petrol-İş 2007).

\section{Transnational Labour Solidarity}

In contrast to the nation-statist outlook of Türk-Işs, Petrol-Işs is among the most internationalist unions in Turkey. It has been affiliated with international unions since 1960 - including ICEM and EMCEF since 1996 and 2000 , respectively, - and has increasingly emphasized the need for unions to replace a 'narrow nationalist union understanding' with a globalist one that can match the globalization of capital (Öztaşkın 2005). Reflecting such a concern with union co-operation across borders, Petrol-İş was a founding member of the Regional Energy Trade Unions Network of South East Europe in 2006. Its internationalist position is reflected also in its general approach to globalization: While opposed to the dominance of capital in the current world political economy, it nonetheless sees global capital as offering opportunities both for organizing in Turkey, and for unions to 'overcome the national barriers restricting the working class struggle'. ${ }^{9}$ The Novamed experience seems to have strengthened Petrol-İş's internationalist conception of the labour struggle.

With respect to the post-strike situation at Novamed, there is no doubt that external union support will be forthcoming in the case that Petrol-İş members are subjected to overt anti-union treatment of the kind that allegedly occurred earlier. ${ }^{10}$ In itself, however, this does little to eradicate the workers' sense of insecurity related to being organized. Against this background, one can ask what external unions can do in relation to the current situation at Novamed. At the most general level, they can intensify their efforts to name and shame Turkey as a country in which 'full trade union rights have yet to be established', and 'private sector employers tend to ignore the law' with limited consequences (ITUC 2009). While such naming and shaming has thus far had limited impact, the process of Turkey's accession to the EU implies that Turkey will sooner or later have to shape up its act with respect to labour rights. In this connection, external unions can contribute by putting more pressure on both Turkey and the EU in an attempt to make sure that the required changes are implemented sooner rather than later. While this is a task suitable for ETUC in particular, it should be noted that ICEM engages regularly in activities aimed at putting issues on the political agenda in Turkey, and, together with EMCEF, has also sought to mobilize 'European governments and OECD contacts in the context of Turkey's application to join the EU' (Routledge and Cumbers 2009: 144).

(C) Blackwell Publishing Ltd/London School of Economics 2010. 
External unions can also put pressure on FMC to make an explicit commitment to basic labour rights, firmly embed them in the corporate culture across all FMC units, and develop credible procedures for monitoring and enforcement across countries of operation. As of today, FMC has a Corporate Compliance Program that is very limited in terms of coverage, has yet to be implemented throughout the company, and rests on a non-transparent system of in-house monitoring. ${ }^{11}$ Against this background, there is a good basis for unions both to put pressure on the FMC management to incorporate explicit reference to core labour rights in its compliance program, and to actively monitor its implementation around the world. However, given the weaknesses that inhere in unilateral codes of conduct, unions can more meaningfully propose for a Global Framework Agreement (GFA) being established between ICEM and FMC - or to take account of the vertically integrated nature of FMC, between ICEM and Public Services International (PSI) on the one hand and FMC on the other. ${ }^{12}$ Through such an agreement, FMC would commit itself to uphold core labour standards in all subsidiaries, and unions would play a central role in monitoring compliance. While GFAs also have well-known weaknesses (Croucher and Cotton 2009: 57-68), a prospective GFA between ICEM/PSI and FMC can nonetheless contribute to create a space within which Novamed workers can feel more secure when organized.

In parallel to this, external unions can promote and contribute to the establishment of a cross-border union or workers' network within FMC that can share information, co-ordinate activities and take on the company more collectively. As of today, a network exists in the form of the Fresenius SE Works Council (FWC), which currently has 30 members from 23 EU countries. While primarily a tool for social dialogue between management and employees, European Work Councils (EWCs) 'provide new horizontal networks of employee representatives across Europe and create new opportunities for information exchange, the formulation of transnational trade union responses and strategy and even active solidarity across national divides' (Wills 2001: 484). As Turkey is currently external to FWC's geographical scope, external unions can at a minimum propose for its inclusion as an EU applicant country (EWC 2007). Given the global nature of FMC's operations, however, a meaningful union or workers' network within FMC must extend beyond Europe. In consequence, external unions can either seek to globalize the FWC, or take an initiative to the establishment of an independent 'global corporate network' (GCN) within FMC. Whether at the European or global level, inclusion in a network can contribute to Novamed workers feeling more secure when organized.

As of today, the prospects for deeper and more proactive solidarity support on the part of external unions are not particularly promising. In this connection, it can initially be stressed that the potential role played by EMCEF would be secondary to those of IG BCE and ICEM. While EMCEF can potentially exert a certain influence on Turkey being included in the FWC - this, through its co-ordination of union involvement in EWCs 
within its sector - initiatives of the kind discussed above must come from IG BCE and ICEM in co-operation with the respective services unions ver.di and PSI. With regard to the establishment of GFAs and GCNs, both IG BCE and ICEM are positive in principle. ICEM is currently party to 13 GFAs, and has made it a strategic priority to develop additional GFAs and deepen its co-operation with other Global Union Federations. Furthermore, ICEM currently has 10 GCNs within in its sector, and both IG BCE and ICEM are open to the establishment of additional networks when feasible. Against this background, the difficulties related to solidarity support in the case at hand concern not the instruments as such, but rather the external unions' strategic orientation and priorities, as well as power relations between and within unions.

In terms borrowed from Martin Upchurch et al. (2009: 160ff.), IG BCE has an integrative (rather than oppositional) socio-political orientation, and a national (rather than international) scale-of-operation orientation. In consequence, international labour solidarity is secondary to its pursuit of social partnership in Germany (Dribbusch and Schulten 2008), and it can therefore not be expected to engage in solidarity actions that can undermine existing partnerships and/or its image as a reliable 'social partner'. While this does not rule out the establishment of GFAs and GCNs, it does rule out efforts to establish both GFAs through adversarial public campaigns and GCNs conceived in oppositional terms. IG BCE's distaste for adversarial mobilization was evident in the Novamed strike, when it primarily took a mediating position and sought to 'tone down' the negative publicity campaign against FMC. ${ }^{13}$ With regard to the current situation at Novamed, IG BCE has a strong sense of FMC not being interested in a GFA, and has no intention to propose, and, if necessary, push them to accept it. ${ }^{14}$ Moreover, IG BCE does not consider there to be a basis for the establishment of a GCN within FMC. While the reason given is that there is no broad-based demand for it, other reasons can be that IG BCE is content with the existing FWC network, that FMC can be anticipated not to like the idea of a broader network, and/or that IG BCE's central office is worried about GCNs undermining its position (Routledge and Cumbers 2009: 151-2). With regard to the FWC, IG BCE and EMCEF have neither a general policy related to Turkey being included in EWCs, nor an intention to propose for Turkey to be included. ${ }^{15}$

Due in part to the influence of IG BCE, both EMCEF and ICEM have to a large extent adopted a 'social-liberal' union position. While this has been the case with EMCEF since its establishment, ICEM began on a different footing by developing a series of policies aimed at countering the power of global capital through 'global unionism' (ICEM 1996). IG BCE opposition to these policies was central to Vic Thorpe's resignation as General Secretary in 1999, and there is currently no prospect of ICEM bypassing IG BCE in an attempt to either force FMC to accept a GFA, or establish a more oppositional GCN. Although considered by its current leadership to have been 'pragmatic' in relation to TNCs from the outset, ${ }^{16}$ there is much to indicate that ICEM has replaced its earlier 'countervailing power' strategy with a

(C) Blackwell Publishing Ltd/London School of Economics 2010. 
more accommodating one centred on social partnership (Routledge and Cumbers 2009: 146). As a final point regarding the prospect for external solidarity related to the current situation at Novamed, it should be noted that IG BCE, EMCEF and ICEM are no longer the only external unions of relevance. Subsequent to FMC's expansion within the health services sector, ver.di is now the dominant union within FMC in Germany, making the European Public Services Union and PSI central to transnational solidarity actions related to FMC. While these unions are closer to Petrol-İs with respect to socio-political orientation, inter-union co-operation outside of Turkey is likely to be hampered not merely by differences in socio-political orientation, but also the tension that to some extent characterizes the relationship between the respective sector unions.

\section{Social Movement Unionism}

Petrol-İş is among a few Türk-İş affiliated unions that have increasingly come to conceive of themselves as being engaged in a broader social struggle involving also non-labour groups. As a left-wing union, Petrol-İş has since long expressed vocal opposition to the neoliberalization of economic policies. It has played an active role in the anti-neoliberal Labour Platform established in 1999, and is a constituent member of the Platform Against Privatization established in 2008. Although Petrol-İş did not participate in the formation of the alter-globalization or global justice movement in Turkey (Baykan and Lelandais 2004), it has more recently become an active participant in the Turkish Social Forum and the European Social Forum (ESF), and is currently a member of the Organizing Committee of ESF 2010 Istanbul. In the wake of the Novamed struggle, Petrol-İş's Administrative Board stressed that ' $[\mathrm{t}]$ he new union understanding [implies] strategic cooperation with social movements in the fight against different forms of suppression', and referred to the 'cooperation [with] the women's liberation movement' as an example of what is needed (Petrol-İş 2008: 4).

With respect to the post-strike situation at Novamed, there is no reason to doubt that support on the part of feminist groups will be forthcoming in the case that women workers are subjected to treatment of the kind that allegedly occurred earlier. In this connection, however, it is important to be clear about the exact basis on which they were mobilized in 2007 - namely, the location of women within a sexist division of labour and patriarchal relations of power at Novamed. In other words, women's mobilization occurred in the context of the broader feminist struggle against patriarchy. In the Novamed case, this struggle went parallel to that of Petrol-İs, which took a clear stance in defence of their rights as workers and women. However, as there is currently little basis for women's groups to engage independently in relation to the Novamed workers, one can ask what building 'mutual support' or 'deep' coalitions (Tattersall 2005) with feminist groups, whose activism is central to engaging the wider women's movement, can contribute with in relation to the current situation at Novamed. 
At the most general level, feminist groups can lend their active support to the ongoing struggle for the protection of basic workers' rights in Turkey this, through campaigns directed at both government authorities and private corporations. Reflecting the union hostile environment that has prevailed in Turkey since 1980, workers' rights have a low status and limited support among people. In parallel to the situation in the USA, a major task for organized labour should therefore be 'to change the cultural climate so that union rights become a cause to which large percentages of the population is dedicated' (Nissen 2004: 68). While unions will have to remove internal characteristics contributing to bring them into disrepute - autocratic structures included (Nichols and Sugur 2004: 165-82) - enlisting the support of feminist groups and the wider women's movement in the struggle for basic workers' rights can help not only to increase the pressure on government authorities to strengthen and enforce the legal framework, but also to confer legitimacy to trade unionisms more generally. With respect to private corporations, the Novamed case is a testimony to the ability of feminists in Turkey to mobilize resources and organize effective public campaigns.

The prospect of feminist groups getting actively engaged in the struggle for the protection of basic workers' rights in Turkey will depend not only on them taking 'a more active stand on societal problems beyond their immediate concerns' (Arat 2008: 418), but also on unions reciprocally participating in the struggle against patriarchy and the oppression of women both within unions and in society at large. In a meeting with the Organizers' Forum in 2006, the Head of the Foundation for the Support of Women's Work expressed that 'they don't work with unions, citing the unions' interest only in "wages, wages, wages". They do not appreciate the interests of women's empowerment' (OF 2006). No workers' union or confederation in Turkey has a women's group of the kind often considered central to the advancement of not merely women workers' interests and gender equality within unions, but also general union goals and revitalization (Parker 2006), and, as stressed by Gülay Toksöz, 'male dominant approaches' imply that 'poor representation of female workers is not seen as a problem, female union members are not encouraged to run for representative organs and such issues as nursing room, childcare facilities, etc.... either remain in shadow or are totally ignored during collective bargaining processes' (Toksöz 2007: 94). ${ }^{17}$

One element feeding into the current situation of mutual neglect and suspicion between the labour and feminist movements in Turkey is the absence of a history of positive interaction, which has been central to co-operation elsewhere (Luxton 2004). Unions and the wider leftist movement in Turkey have often ascribed to "the notion that feminism is a bourgeois phenomenon' (Müftüler-Bac 1999: 307), and 'labour issues were never a priority in the feminist movement' (Marshall 2009: 374). While feminist scholars have since long been concerned with the economic situation of women in Turkey, and women's NGOs are centrally involved in projects promoting women's entrepreneurship, the extensive involvement of feminist groups in both the Novamed case and a few more recent cases seems to 
indicate that labour issues are moving up on their agenda, and that they are becoming more critical of neoliberalism. In this connection, the feminists behind the Women's Platform for Solidarity with Novamed Strikers have established a Socialist Feminist Collective with 'branches' in a few cities, and 27 other feminist groups established a Women's Labor and Employment Initiative Platform (KEİG) in 2006. These developments, together with the bridging position of a limited but important number of union feminists, hold out some promise of closer co-operation between feminist groups and unions taking the struggle against patriarchy seriously. ${ }^{18}$

Shifting focus to the current situation at Novamed, feminist groups can potentially help Petrol-İş to organize more women workers. In this connection, two issues can be emphasized: First, short of Petrol-İs recruiting women organizers, whom some argue can better organize women workers, ${ }^{19}$ feminist groups can contribute to increase the effectiveness of Petrol-Işs's organizing efforts by providing gender training to its male organizers. More specifically, they can enable Petrol-İs to better understand and attend to both the gender relations prevailing at Novamed - including, not least, the gendered job segregation and devaluation of 'women's work' - and the broader and less economistic concerns that are often of great significance to women workers (Forrest 2001). Second, feminist groups can contribute to empower women workers through gender training and consciousness raising - activities that can transform how they see themselves as workers, as well as enable them to challenge patriarchal power relations and make independent decisions related to unionization (Forrest 2001: 669-70; Yates 2006). Beyond organizing, feminist groups can also develop a support network for the organized women workers at Novamed and thereby contribute to their ability to deal with the insecurity related to being organized. One possible way to do this, which can be of relevance also beyond Novamed, would be to establish a centre for women workers in Antalya. In parallel to centres established for low-wage workers in the USA, such a centre can 'engage in a combination of service, advocacy, and organizing to provide support to [women] workers' (Fine 2006: 419).

As in the general case discussed above, the prospect of feminist groups becoming active in relation to the current situation at Novamed is likely to depend on how Petrol-İs positions itself in relation to their concerns. In this connection, although Petrol-İş has become increasingly committed to organizing women workers and improving their working conditions, this has yet to be understood in anti-patriarchal terms. While arguing that the 'patriarchal mentality' in Turkey constitutes an obstacle to organizing - this, because ' $[\mathrm{n}] \mathrm{ot}$ only the decision to work, but also the decision to become a union member, is not made by women on their own' (Petrol-İş 2008: 29) it reproduced that mentality in the Novamed case by directing organizing efforts towards women workers' male family members. Furthermore, Petrol-İs is no less immune than most unions to the charge that they are patriarchal institutions. Irrespective of it being the only union with a women's magazine in Turkey, Petrol-İş has yet to establish a women's 
committee or develop a clear policy related to the rights and concerns of women workers, and is completely male dominated at the top of its organization. That said, it should be mentioned that Petrol-İş has established a separate budget for women, it launched a gender training program in early 2009, and women's committees have been established in a few branches.

Although Petrol-Işs has yet to formulate and implement a clear strategy related to 'strategic co-operation' with non-labour movements in general and the women's movement in particular, there has been some post-strike contact between Petrol-i̇ş and feminist groups. First, Petrol-işs Kadın is a founding member of KEIG. Second, a conference on 'women labour confronting neoliberal transformations' was organized in Petrol-İss's facilities in April 2008. Third, together with two other unions and the Centre for Social Research and Education, Petrol-İş invited feminist groups to a discussion on the situation of women workers in the context of the economic crisis in November 2008, and this led to the establishment of a Women's Solidarity Network Against the Economic Crisis in January 2009. Fourth, Petrol-İs facilitated a training session on 'women's body rights and reproductive health' for Novamed women workers that was co-organized by the Antalya Women's Counselling and Solidarity Centre in March 2009. Despite this, it remains to be seen if a coalition of sorts will develop between Petrol-İş and feminist groups at the central and/or local level, and if closer contact will be established between the Novamed workers and local feminist groups.

\section{Concluding remarks}

In connection with the crisis experienced by unions around the world, the union revitalization literature has identified a series of strategies that unions either have adopted or can adopt in order to (re)assert themselves, and emphasized both that the strategies in question are not mutually exclusive, and that unions can often benefit from pursuing several of them in parallel (Frege and Kelly 2004). While a large number of factors are seen to influence the strategic choice made by unions, great importance is commonly ascribed to 'national' context - hence, the dominance of national case studies and comparative research. Although this makes sense to some extent, the methodological nationalism involved can easily result in a neglect of important differences within national union movements. In the relevant case of Germany, for instance, IG BCE has maintained a strong commitment to 'social partnership', while IG Metall and ver.di have increasingly pursued a strategy of " "countervailing power" [both] against employers and government alike' (Addison et al. 2007: 16), and together with other social movements (Dribbusch and Schulten 2008: 191-2).

Irrespective of the ideological differences found within Turkey's fragmented union movement, all unions have suffered from the legacy of military rule and post-1980 neoliberal economic policies, and the downward trend in unionization is likely to continue if unions succumb to fatalism, or refuse to 
accept that changing conditions require strategic rethinking. Although it is beyond the scope of this article to engage in detail with the opportunitist debate on union revitalization in Turkey (Sazak 2006; Yücesan-Özdemir and Özdemir 2007), a few general comments are nonetheless warranted. First, organizing must be part of any strategy of (re)vitalization, and the same goes for much needed internal reform aimed at fostering democracy and participation. Second, rather than playing the competitive game promoted by labour laws, unions and confederations need to intensify co-operation among themselves, the potential for which currently seems the greatest among leftwing confederations and unions affiliated with Türk-İs. Third, while unions should intensify political campaigning aimed at improving the legal framework of industrial relations, party-political engagements are problematic with formal union-party connections being unlawful, and informal connections tending to serve the interests of autocratic union leaders - but can provide opportunities if embedded in a radicalized conception of political unionism linked to social movement unionism (Upchurch et al. 2009). Fourth, given the highly unequal relationship between labour and capital in Turkey, unions are likely to have little to gain from pursuing social partnership.

With respect to transnational solidarity and coalition building, our study sheds light on both the opportunities and challenges involved. On the one hand, the Novamed case shows that solidarity across borders and social groups can make a positive difference of great significance - this, to the extent of it being considered a 'best practice' case. ${ }^{20}$ While the external labour support could have been greater and more effective if it had been mobilized beyond industry-specific channels of solidarity and/or if the engagement had moved beyond union officials to include ordinary workers, there is no doubt that solidarity actions on the part of IG BCE, EMCEF and ICEM contributed significantly to both the organizing and the conclusion of a collective agreement at Novamed. Likewise, although the support mobilized by feminists could also have been greater and more effective - if, for instance, they had been better connected with women's groups outside of Turkey - there is no doubt that the women's platforms contributed significantly to make the Novamed workers' conditions and struggle visible, and put pressure on the FMC management to resolve the conflict.

On the other hand, the Novamed case also points to significant challenges or limits related to the development of a deeper and more proactive form of solidarity. With regard to cross-border union solidarity, differences in both socio-political and scale-of-operation orientation among national sector unions can prevent the development of the common identity and interests that such solidarity requires. Furthermore, when such differences do exist, actions on the part of international unions are likely to be constrained by the position of the most influential ones. Lastly, in cases of vertically integrated companies like FMC, differences in strategic orientation among unions across sectors are likely to complicate the development of solidarity actions even further. With regard to solidarity across social groups, the 
building of coalitions is likely to be hampered when relations among potential partners are either non-existent or characterized by mutual suspicion. For both unions and other social movements, it is a great challenge to leave behind old ways of thinking and doing and engage as equal partners in a broader social struggle for justice.

While recognizing the challenges involved, we consider transnational solidarity and coalition-building not merely to offer significant opportunities for unions in Turkey, but to be a necessity if they are to (re)assert themselves. While the national scale remains an important site of struggle, the transnational re-organization of production simply cannot be challenged there alone. Furthermore, the marginalizing effects of neoliberal restructuring have left unions with few options but to seek a broadening of the social basis for its struggle. The extent to which unions will be able to act on the available opportunities will to a large extent depend on strategy and commitment. With respect to transnational solidarity, unions must promote a better external understanding of industrial relations in Turkey, actively nurture relations with like-minded unions abroad, and collectively seek to influence the strategies and activities of Global Union Federations. With respect to coalition building, unions must contribute to the development and strengthening of a 'master frame' that can unite more specific struggles (Carroll and Ratner 1996), actively nurture relations with relevant coalition partners, and prove in practice that they are committed to and reliable partners in a struggle against multiple forms of injustice. With respect to a prospective coalition with feminist groups, this implies that they will first and foremost have to re-constitute themselves in anti-patriarchal terms.

Final version accepted on 28 March 2010.

\section{Acknowledgements}

We are grateful to the editor and referees for comments and suggestions on an earlier version.

\section{Notes}

1. Interview, Novamed Chief Financial Officer, 24 November 2008.

2. Note that strike action is prohibited by law in certain fields of economic activity, and that the government can postpone strikes for 60 days due to public health or national security concerns.

3. The management denied the existence of such working conditions during the conflict (Petrol-İs 2008: 53), and has referred to the allegations as 'completely false accusations' (Interview, Novamed General Manager, Operational Manager and Chief Financial Officer, 7 April 2010).

4. These allegations have also been rejected as 'completely false accusations', and the management has claimed that it was rather Petrol-İş and union members who 
engaged in intimidation and blackmailing (Interview, Novamed General Manager, Operational Manager and Chief Financial Officer, 7 April 2010).

5. Interview, Petrol-İs lawyer, 8 February 2008. A strike ballot is arranged if one-fourth of the employees ... request it in writing within six working days following the [strike] announcement' (Dereli 2006: 339).

6. According to Petrol-Isş, Novamed also made extensive use of overtime work and scab workers during the strike. These claims were rejected by the Antalya Labour Court in August 2007, and Petrol-İş withdrew its appeal when a resolution to the conflict was forthcoming.

7. Interview, Novamed General Manager, Operational Manager and Chief Financial Officer, 7 April 2010.

8. The women's movement in Turkey is heterogeneous, and it is common to distinguish between Kemalist, feminist, socialist, liberal, Muslim, and Kurdish women's groups (Arat 2008; Coşar and Onbaşi 2008). Despite co-operation enabled by the discourse on women's human rights, these groups do not share a feminist discourse, and we therefore limit our use of the term 'feminist' to women self-consciously engaged in politics from a 'women's perspective' before anything else.

9. Interview, Petrol-İş General Secretary, 10 October 2008; Petrol-İş proposal for ESF 2008 (http://openesf.net/projects/labour-and-globalization/lists/esf-labourglobalization/archive/2008/04/1209378137182) (accessed 5 November 2008).

10. Telephone Interviews, IG BCE Head of International Department, 6 July 2009, EMCEF General Secretary, 7 September 2009, and ICEM General Secretary, 21 August 2009.

11. Information about the compliance program is available on FMC's webpage (http://www.fmc-ag.com/tbhtm).

12. Petrol-İş requested for IG BCE to consider taking an initiative to the establishment of a GFA with FMC in August 2008.

13. Telephone interview, IG BCE Head of International Department, 6 July 2009.

14. Telephone interview, IG BCE Head of International Department, 6 July 2009.

15. Email communication, EMCEF Official, 6 July 2009.

16. Telephone interview, ICEM General Secretary, 21 August 2009.

17. In 2009, women officials constituted $6.5,6.7,9.7$ and 8.7 per cent of chairpersons, managing committee members, supervisory committee members and disciplinary committee members, respectively (MLSS 2009: 120).

18. On the importance of bridging institutions and individuals in general and union feminists in particular, see, respectively, Ferree and Roth (1998) and Fonow and Franzway (2007).

19. While this is clearly the case from a 'women's ways of organizing' perspective, it is less clear-cut from a 'women's issues' perspective (Rooks 2003: 38-9).

20. Telephone interview, ICEM General Secretary, 21 August 2009.

\section{References}

Adaman, F., Buğra, A. and İnsel, A. (2009). 'Societal context of labor union strategy: the case of Turkey'. Labor Studies Journal, 34 (2): 168-88.

Addison, J. T., Schnabel, C. and Wagner, J. (2007). 'The (parlous) state of German unions'. Journal of Labor Research, 28 (1): 1-18. 
Arat, Y. (2008). 'Contestation and collaboration: women's struggles for empowerment in Turkey'. In R. Kasaba (ed.), The Cambridge History of Turkey: Turkey in the Modern World, Vol. 4. Cambridge: Cambridge University Press, pp. 388 418.

Baykan, B. G. and Lelandais, G. E. (2004). 'Cross-readings of the anti-globalisation movement in Turkey and beyond: political culture in the making'. International Social Science Journal, 182: 519-28.

Bieler, A., Lindberg, I. and Pilay, D. (eds) (2008). Labour and the Challenges of Globalization: What Prospects for Transnational Solidarity? London: Pluto Press.

Carroll, W. K. and Ratner, R. S. (1996). 'Master framing and cross-movement networking in contemporary social movements'. The Sociological Review, 37 (4): 601-25.

Çelik, A. and Lordoğlu, K. (2006). 'Türkiye'de resmi sendikalaşma istatitiklerinin sorunları üstüne'. Çalıșma ve Toplum, 2: 11-29.

Coşar, S. and Onbaşi, G. (2008). 'Women's movement in Turkey at a crossroads: from women's rights advocacy to feminism'. South European Society and Politics, 13 (3): $325-44$.

Croucher, R. and Cotton, E. (2009). Global Unions, Global Business: Global Union Federations and International Business. London: Middlesex University Press.

Dedeoğlu, S. (2008). Women Workers in Turkey: Global Industrial Production in Istanbul. London: Tauris.

Dereli, T. (2006). Labour Law and Industrial Relations in Turkey. Alphen aan den Rijn: Kluwer.

Dribbusch, H. and Schulten, T. (2008). 'German trade unions between neoliberal restructuring, social partnership and internationalism'. In A. Bieler, I. Lindberg and D. Pilay (eds), Labour and the Challenges of Globalization: What Prospects for Transnational Solidarity? London: Pluto Press, pp. 178-98.

EWC (2007). 'Turkey: A Topic for the EWC?'. EWC News, No. 2.

Ferree, M. M. and Roth, S. (1998). 'Gender, class, and the interaction between social movements: a strike of West Berlin day care workers'. Gender and Society, 12 (6): 626-48.

Fine, J. (2006). 'Worker centers: organizing communities at the edge of the dream'. New York Law School Law Review, 50 (2): 417-63.

FMC (2009). Living Confidence: Annual Report 2008. Bad Homburg: FMC.

Fonow, M. M. and Franzway, S. (2007). 'Transnational union networks, feminism and labour advocacy'. In V. Schmidt (ed.), Trade Union Responses to Globalizaton: A Review by the Global Union Research Network. Geneva: ILO, pp. 165-75.

Forrest, A. (2001). 'Connecting women and unions: what are the issues?'. Relations industrielles/Industrial Relations, 56 (4): 647-75.

Fougner, T. and Kurtoğlu, A. (2010). 'Victory through solidarity? The story of a women workers' strike in Turkey's Antalya Free Zone'. In A. Bieler and I. Lindberg (eds), Global Restructuring, Labour and the Challenges for Transnational Solidarity. London: Routledge.

Frege, C. M. and Kelly, J. (eds) (2004). Varieties of Unionism: Strategies for Union Revitalization in a Globalizing Economy. Oxford: Oxford University Press.

IBRD (1980). 'Turkey — structural adjustment loan project (supplement)'. Report, No. P2888.

ICEM (1996). Power and Counterpower: The Union Response to Global Capital. London: Pluto Press. 
ITUC (2008). 'Turkey'. In: Annual Survey of Violations of Trade Union Rights 2008. Available at: http://survey08.ituc-csi.org

— (2009). 'Turkey'. In: Annual Survey of Violations of Trade Union Rights 2009. Available at: http://survey09.ituc-csi.org

Korine, H. (2000). 'Fresenius AG: high-speed globalization'. Business Strategy Review, 11 (2): 47-57.

Kurtoğlu, A. and Fougner, T. (2008). “ "Küresel Sermayeye Karşı Küresel Kadın Dayanışması": Novamed Grevi ve Ötesi'. Paper presented at Conference on Gender Studies in Turkey: Inequalities, Struggles and Advances. Istanbul, 29-30 November.

Lee, E. (2006). 'Global campaigning: beyond protest emails and solidarity messages'. Available at: http://www.ericlee.info/2006/02/global_campaigning_beyond_prot. html

Luxton, M. (2004). 'On feminism and the labor movement in Canada: a response to Dan Clawson'. Labor History, 45 (3): 370-6.

Mackintosh, M. and Koivusalo, M. (eds) (2005). Commercialization of Health Care: Global and Local Dynamics and Policy Responses. Basingstoke: Palgrave Macmillan.

Marshall, G. A. (2009). 'Authenticating gender policies through sustained pressure: the strategy behind the success of Turkish feminists'. Social Politics, 16 (2): 358-78.

MLSS (2009). Labour Statistics 2008. Ankara: MLSS.

Moody, K. (1997). 'Towards an international social-movement unionism'. New Left Review, 225: 52-72.

Müftüler-Bac, M. (1999). 'Turkish women's predicament'. Women's Studies International Forum, 22 (3): 303-15.

Nichols, T. and Sugur, N. (2004). Global Management, Global Labour: Turkish Workers and Modern Industry. Basingstoke: Palgrave Macmillan.

Nissen, B. (2004). 'The effectiveness and limits of labor-community coalitions: evidence from South Florida'. Labor Studies Journal, 29 (1): 67-89.

OF (2006). 'An International Dialogue on Organizing in Turkey'. Summary Notes on Dialogue \#12 of the Organizers' Forum. Available at: http://organizersforum.org/ index.php?id=1786.

Öniş, Z. (1998). State and Market: The Political Economy of Turkey in Comparative Perspective. Istanbul: Boğaziçi University Press.

Öztaşkın, M. (2005). 'Sadece sendikaların krizi mi? İşçi sınıfı hareketinin krizi mi?'. In F. Sazak (ed.), Sendikal Kriz Yaklaşımları: Sendikalar 'Krizi' Tartışıyor. Ankara: Epos, pp. 150-8.

Parker, J. (2006). 'Trade union women's groups and their effects on union goals and strategies'. Human Resource Management Journal, 16 (4): 411-31.

Petrol-Işs (2007). 25. Olağan Genel Kurulu Çalışma Raporu 2003-2007. Istanbul: Petrol-İș.

_ (2008). Novamed Grevi: Küresel Sermayeye Karşı Küresel Kadın Dayanışması. Istanbul: Petrol-İş.

Robinson, B. (2008). 'Solidarity across cyberspace: internet campaigning, labour activism and the remaking of trade union internationalism'. Work Organisation, Labour and Globalisation, 2 (1): 152-64.

Rooks, D. (2003). 'The cowboy mentality: organizers and occupational commitment in the new labor movement'. Labor Studies Journal, 28 (3): 33-62.

Routledge, P. and Cumbers, A. (2009). Global Justice Networks: Geographies of Transnational Solidarity. Manchester: Manchester University Press. 
Sazak, F. (ed.) (2006). Türkiye’de Sendikal Kriz Ve Sendikal Arayıslar. Ankara: Epos. Tattersall, A. (2005). 'There is power in coalition: a framework for assessing how and when union-community coalitions are effective and enhance union power'. Labour and Industry, 16 (1): 97-112.

Toksöz, G. (2007). Women's Employment Situation in Turkey. Ankara: ILO.

Upchurch, M., Taylor, G. and Mathers, A. (2009). The Crisis of Social Democratic Unionism in Western Europe: The Search for Alternatives. Farnham: Ashgate.

Weisband, E. and Öner, S. (2007). 'So near, yet so far: freedom of association and worker's rights'. In Z. F. K. Arat (ed.), Human Rights in Turkey. Philadelphia, PA: University of Pennsylvania Press, pp. 105-22.

Wills, J. (2001). 'Uneven geographies of capital and labour: the lessons of European Works Councils'. Antipode, 33 (3): 484-509.

Yates, C. (2006). 'Challenging misconceptions about organizing women in unions'. Gender, Work and Organization, 13 (6): 565-84.

Yildrim, E. and Calis, S. (2008). 'The impact of EU accession on Turkish industrial relations and social dialogue'. Industrial Relations Journal, 39 (3): 212-28.

Yücesan-Özdemir, G. and Özdemir, A. M. (2007). 'Trade unionism in Turkey'. In C. Phelan (ed.), Trade Union Revitalisation: Trends and Prospects in 34 Countries. Oxford: Peter Lang, pp. 461-74. 